\title{
The Influence of Water Hyacinth Floating Meadows on Limnological Characteristics in Shallow Subtropical Waters
}

\author{
Sylvina L. Casco ${ }^{1,2}$, Romina P. Carnevali1 ${ }^{12}$, Alicia S. G. Poi ${ }^{1,2}$, Juan J. Neiff ${ }^{1}$ \\ ${ }^{1}$ Centro de Ecología Aplicada del Litoral (CONICET-UNNE), Corrientes, Argentina \\ ${ }^{2}$ Facultad de Ciencias Exactas y Naturales y Agrimensura (UNNE), Corrientes, Argentina \\ Email: sylvina.casco@gmail.com
}

Received 24 April 2014; revised 24 May 2014; accepted 15 June 2014

Copyright (C) 2014 by authors and Scientific Research Publishing Inc.

This work is licensed under the Creative Commons Attribution International License (CC BY). http://creativecommons.org/licenses/by/4.0/

c) (i) Open Access

\section{Abstract}

The effects of free-floating mats of the water hyacinth Eichhornia crassipes (Mart.) Solms on the limnological characteristics of two lakes located on the fringing floodplain of the lower Paraná River $\left(2^{\circ} 27^{\prime} \mathrm{S}, 5^{\circ} 55^{\prime} \mathrm{W}\right)$ were studied monthly between April 1998 and April 1999 . The mobility of the free-floating vegetation at both locations prevented continual observation. Therefore, to carry out the intensive sampling needed for this study, two experimental ponds (A and B) were filled with water from the Paraná River in 1996. Pond A was designed to reproduce conditions similar to those of lakes vegetated with water hyacinth. Pond B was designed to recreate the limnological conditions of these lakes, such as a high concentration of dissolved and fine particulate organic matter and a peat layer on the bottom; however, pond B lacked macrophytes. Natural lakes covered with free-floating vegetation were very similar to pond $A$, but these water bodies showed a lower temperature, dissolved oxygen level and $\mathrm{pH}$ and a higher conductivity than the non-vegetated pond. Our results indicated that water hyacinth has a strong local influence on the limnological conditions in subtropical shallow lakes. Our results may assist in developing causeconsequence models by demonstrating the relevance of the effect of thermal damping produced by floating meadows.

\section{Keywords}

Eichhornia crassipes, Subtropical Lakes, Temperature, Dissolved Oxygen, Electrical Conductivity, pH

\section{Introduction}

Aquatic macrophytes influence the quality of water bodies by providing organic matter and by influencing nu-

How to cite this paper: Casco, S.L., Carnevali, R.P., Poi, A.S.G. and Neiff, J.J. (2014) The Influence of Water Hyacinth Floating Meadows on Limnological Characteristics in Shallow Subtropical Waters. American Journal of Plant Sciences, 5, $1983-1994$. 
trient dynamics as well as the retention and transport of organic and inorganic silts [1]-[7].

Eighty percents of the lakes and ponds of the lower Paraná floodplain are covered with floating plants, and the dominant aquatic plant species is Eichhornia crassipes (Mart.) Solms (water hyacinth) [4] [8]. Floating meadows, which may cover from $<5 \%$ to $100 \%$ of the available surface of these lakes [1] [9], interfere significantly with light penetration into the water and restrict photosynthesis due to increased sedimentation and shading of the water column, which leads to deoxygenation and has a detrimental impact on aquatic organisms, particularly fish [10], zooplankton [11] and periphyton [12]. Other water quality effects include higher sedimentation rates within the plant's complex root structure and the capture of inorganic phosphorus during floods [13].

In these lakes, water circulation is reduced to a daily period of mixing, which occurs during the morning [3]. The floating meadows of water hyacinth produce a mean of $5.1 \mathrm{~g} \cdot \mathrm{m}^{-2} \cdot \mathrm{day}^{-1}$ of organic matter [13] using a significant amount of nutrients, mainly nitrogen and phosphorus [1] [3].

During the decomposition process, specifically through leaching and the mineralization of organic matter, floating meadows release nutrients and organic compounds that influence the chemistry of the surrounding waters [3]. This process depends on the oxygen concentration in the water [12] [14]; thus, there is a feedback loop between the physical and chemical conditions of lakes and the growth of water hyacinth. The nitrate content of water is the most important external variable that influences the decay rates of E. crassipes in different floodplain lakes of the Paraná River [15]. The effects of aquatic vegetation on the environmental characteristics of floodplain lakes in tropical rivers remain poorly understood, despite the great scientific interest in understanding the dynamics of other communities. Most previous studies have been focused on the environmental factors that determine the distribution of aquatic plants [16]-[18].

The aim of this study was to assess the influence of E. crassipes floating meadows on four limnological variables (temperature, dissolved oxygen, electrical conductivity and $\mathrm{pH}$ ) in floodplain lakes of the Paraná River over the course of one year. The effects of vertical stratification and daily variation were studied in two experimental ponds: one with and one without E. crassipes cover.

We tested the following hypotheses: 1) E. crassipes cover determines the depletion of dissolved oxygen; 2) water temperature, electrical conductivity and $\mathrm{pH}$ differ between ponds with and without water hyacinth; and 3) limnological water conditions vary daily as a consequence of the cover provided by E. crassipes floating meadows.

\section{Materials and Methods}

\subsection{Study Site}

To study the effects of water hyacinth on the limnological characteristics of water, two natural lakes-El Puente and San Nicolás-were selected. These lakes are located on the west bank of the Paraná River within the Ramsar site in Chaco, Argentina. Because lakes situated on the river floodplain are regularly flooded, experiments with enclosures in floodplain lakes could only be performed over a short period of time due to frequent river overflow [3]. Thus, to prevent the mobility of E. crassipes floating meadows in one-year-long experiments, two experimental ponds located $12 \mathrm{~km}$ from the river course were used. These ponds, which were constructed of cement, were previously used in an experimental study [10].

The lakes belong to a complex of several similar lakes and ponds (Figure 1) located parallel to, and approximately $2 \mathrm{~km}$ from, the river [19]. Typical floodplain lakes of this area are small (200 × $2000 \mathrm{~m})$, shallow (0.4 $2 \mathrm{~m}$ deep) and separated from the river by alluvial levees (20 m wide, 1 - $2 \mathrm{~m}$ high) occupied by gallery forests. As river water enters the floodplain lakes, dissolved inorganic nitrogen, especially $\mathrm{NO}_{3}$, increases to high levels. At a high water level, phosphate concentrations vary between 50 and $105 \mu \mathrm{g} \cdot \mathrm{l}^{-1}$ and show slight changes during and after the flood [3] [20].

Lake San Nicolás $\left(27^{\circ} 27^{\prime} \mathrm{S}, 58^{\circ} 55^{\prime} \mathrm{W}\right)$ connects to the Paraná River one to three times per year, and during this study, water hyacinth covered $70 \%$ - $90 \%$ of its surface and grew to a depth of $1.50-2.00 \mathrm{~m}$.

Lake El Puente $\left(26^{\circ} 26^{\prime} \mathrm{S}, 58^{\circ} 51^{\prime} \mathrm{W}\right)$ suffers more frequent long-lasting flooding events than Lake San Nicolás [19], and water hyacinth covered $40 \%$ - $60 \%$ of its surface with a depth range similar to that observed in Lake San Nicolás.

Ponds $\mathrm{A}$ and $\mathrm{B}$, located at $27^{\circ} 28^{\prime} \mathrm{S}$ and $58^{\circ} 44^{\prime} \mathrm{W}$ with dimensions of $10 \mathrm{~m} \times 2.10 \mathrm{~m}$ and depths of $1.60 \mathrm{~m}$, were filled with water from the Paraná River. The chemical conditions of these ponds were similar to those of the floodplain lakes. Organic matter on the bottom of both ponds was the result of E. crassipes decomposition. 


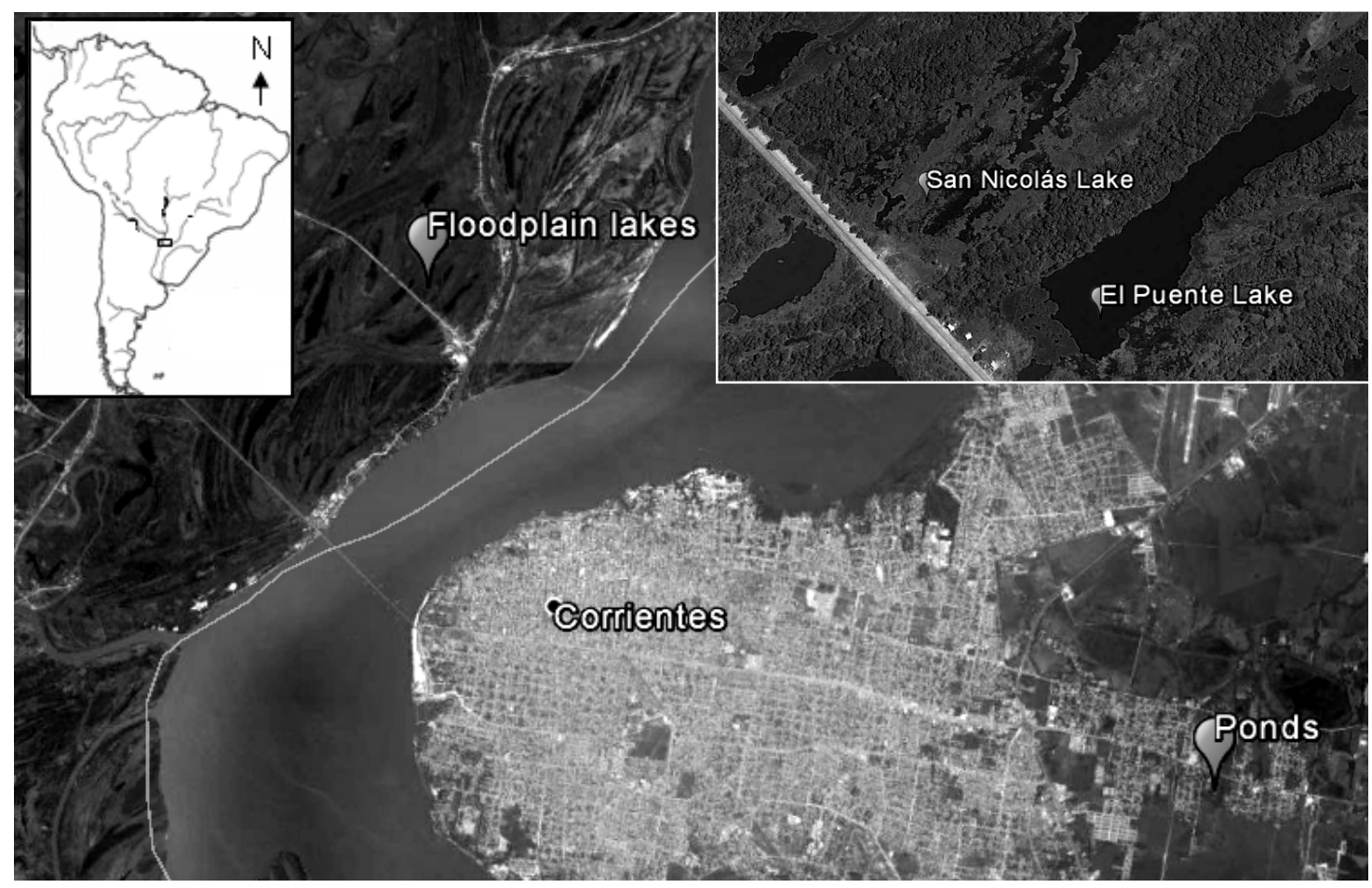

Figure 1. Location of the sampling sites on the Paraná River floodplain.

Water lost due to evaporation and evapotranspiration was replaced with river water. Pond A was stocked to a surface coverage of $90 \%$ with water hyacinth plants with elongated leaves (large biotype), which occur in dense mats; in pond $\mathrm{B}$, water hyacinth was absent.

\subsection{Sampling}

Sampling operations were performed for one year (from April 1998 to April 1999) on the natural lakes and the experimental ponds. Due to the movement of floating meadows and access limitations in the field area, the measurements of the floodplain lakes were performed once a month at 9 a.m. at a depth of $20 \mathrm{~cm}$. The experimental ponds were sampled at 8 a.m. and at 2 p.m. at 3-day intervals, following a vertical profile of 0.10, 0.20, $0.50,1.0$ and $1.5 \mathrm{~m}$ depth.

Water temperature and oxygen concentration were measured with a YSI 54A polarographic probe, conductivity was recorded with a YSI 33 SCT device, and pH was measured with a WTW 330/SET-1 digital pH meter. Vertical profiles were recorded for the mentioned variables except $\mathrm{pH}$, which was measured at $10 \mathrm{~cm}$.

Air temperature records were obtained from the National Institute of Agricultural Technology (INTA) Colonia Benítez, which is located $5 \mathrm{~km}$ from the lakes.

\subsection{Data Analysis}

Water variables from both lakes, from both experimental ponds (A and B), and from ponds and natural lakes were compared with one-way ANOVA and post hoc LSD Fisher tests using InfoStat statistical software [21]. The data were $\log (x+1)$ transformed if necessary to reduce heterogeneity of variances.

Variations in the water variable profiles (temperature, dissolved oxygen and electrical conductivity) between the ponds and between the floodplain lakes were tested using MANOVA at a significance level of p $<0.01$ [21].

\section{Results}

\subsection{Limnological Conditions in Floodplain Lakes}

Except for the fact that dissolved oxygen was significantly higher in Lake El Puente than in Lake San Nicolás 
(Table 1), we did not find limnological differences between the floodplain lakes. Lake El Puente connects more frequently with the Paraná River than Lake San Nicolás, and the dissolved oxygen content of these lakes varied between 2.6 and $6.3 \mathrm{mg} \cdot \mathrm{L}^{-1}$ and between 0 and $5 \mathrm{mg} \cdot \mathrm{L}^{-1}$, respectively (Figure 2(a)). Anoxic conditions were found during the summer due to the dense cover of $E$. crassipes and the high temperature.

No significant differences in temperature, electrical conductivity or $\mathrm{pH}$ were observed between the lakes during the study period (Table 1, Figures 2(b)-(d)). Minimum values were registered in June, when the Paraná River was in its high water period. The highest values of water temperature occurred in February $\left(23.8^{\circ} \mathrm{C}\right.$ in Lake San Nicolás and $27^{\circ} \mathrm{C}$ in Lake El Puente, Figure 2(b)) and were coincident with the maximum air temperature (Figure 3).

The maximum values of electrical conductivity $\left(340 \mu \mathrm{S} \cdot \mathrm{cm}^{-1}\right)$ and $\mathrm{pH}(8.23)$ were higher in Lake San Nicolás than in Lake El Puente (290 $\mu \mathrm{S} \cdot \mathrm{cm}^{-1}$ and 7.98 units, Figure 2(c) and Figure 2(d)).

During the study period, the mean air temperature ranged between $9.3^{\circ} \mathrm{C}$ in September and $31.4^{\circ} \mathrm{C}$ in December (Figure 3).

The MANOVA results suggested that there were no significant differences between the floodplain lakes $(\mathrm{F}=$ 2.32; $\mathrm{p}<0.1032$ ).

\subsection{Limnological Conditions in Experimental Ponds}

The vertical profiles of the limnological variables at 8 a.m. and 2 p.m. were significantly different in both ponds (Table 1). During the study period, dissolved oxygen in pond A was always lower than that in pond B (below 4 $\mathrm{mg} \cdot \mathrm{L}^{-1}$ and below $7 \mathrm{mg} \cdot \mathrm{L}^{-1}$ at $8 \mathrm{a} . \mathrm{m}$. and $2 \mathrm{p} . \mathrm{m}$. respectively), and anoxic conditions were noted at the bottom (Figure 4(a) and Figure 5(a)).

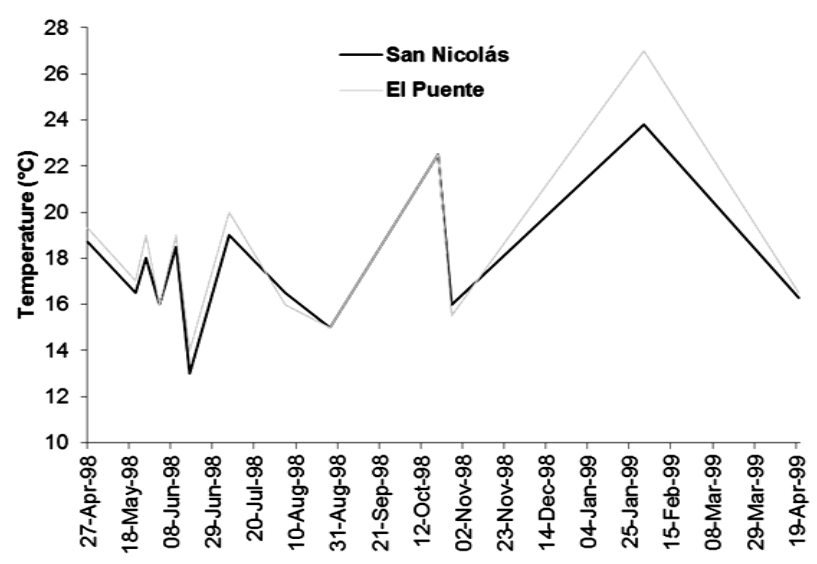

(a)

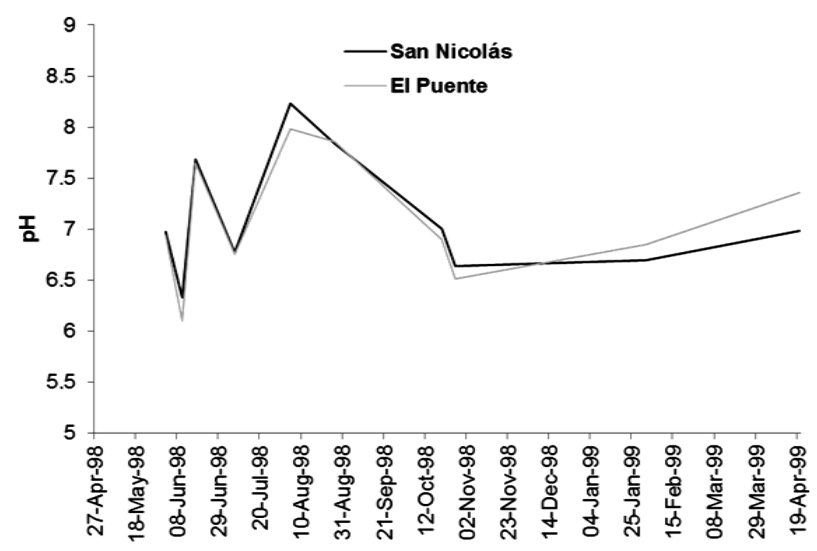

(c)

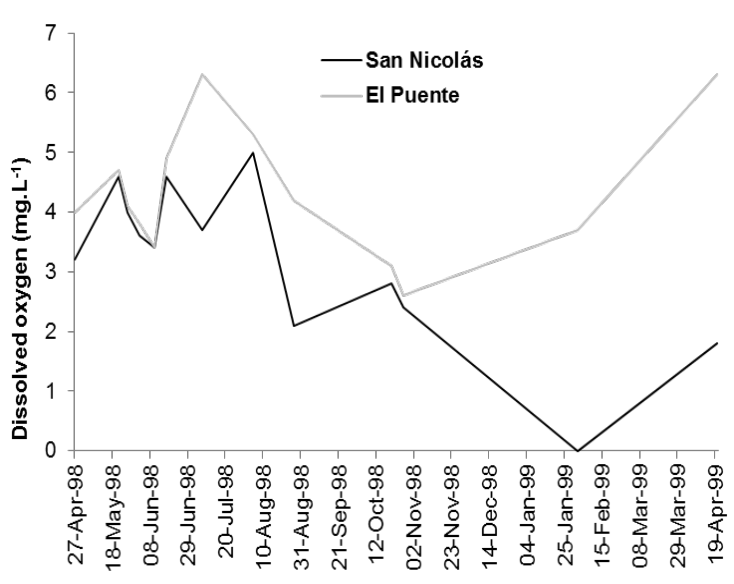

(b)

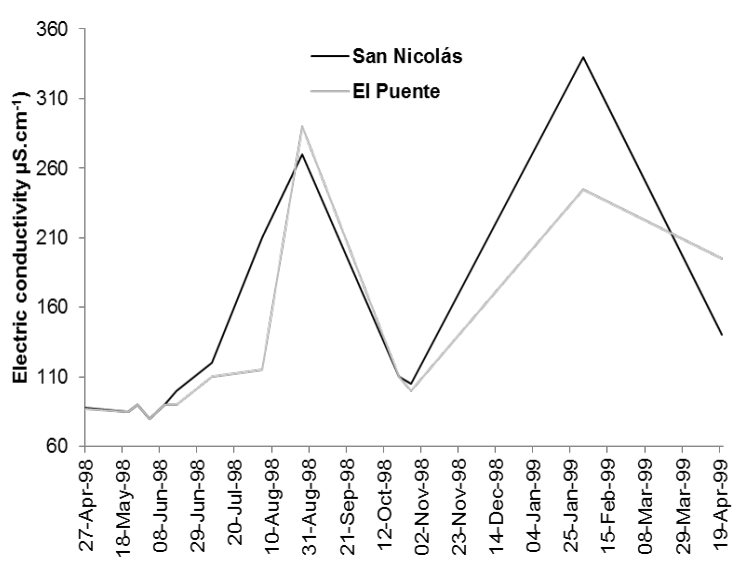

(d)

Figure 2. Variability of dissolved oxygen (a); temperature (b); electrical conductivity (c); and pH (d) values in the natural lakes. 


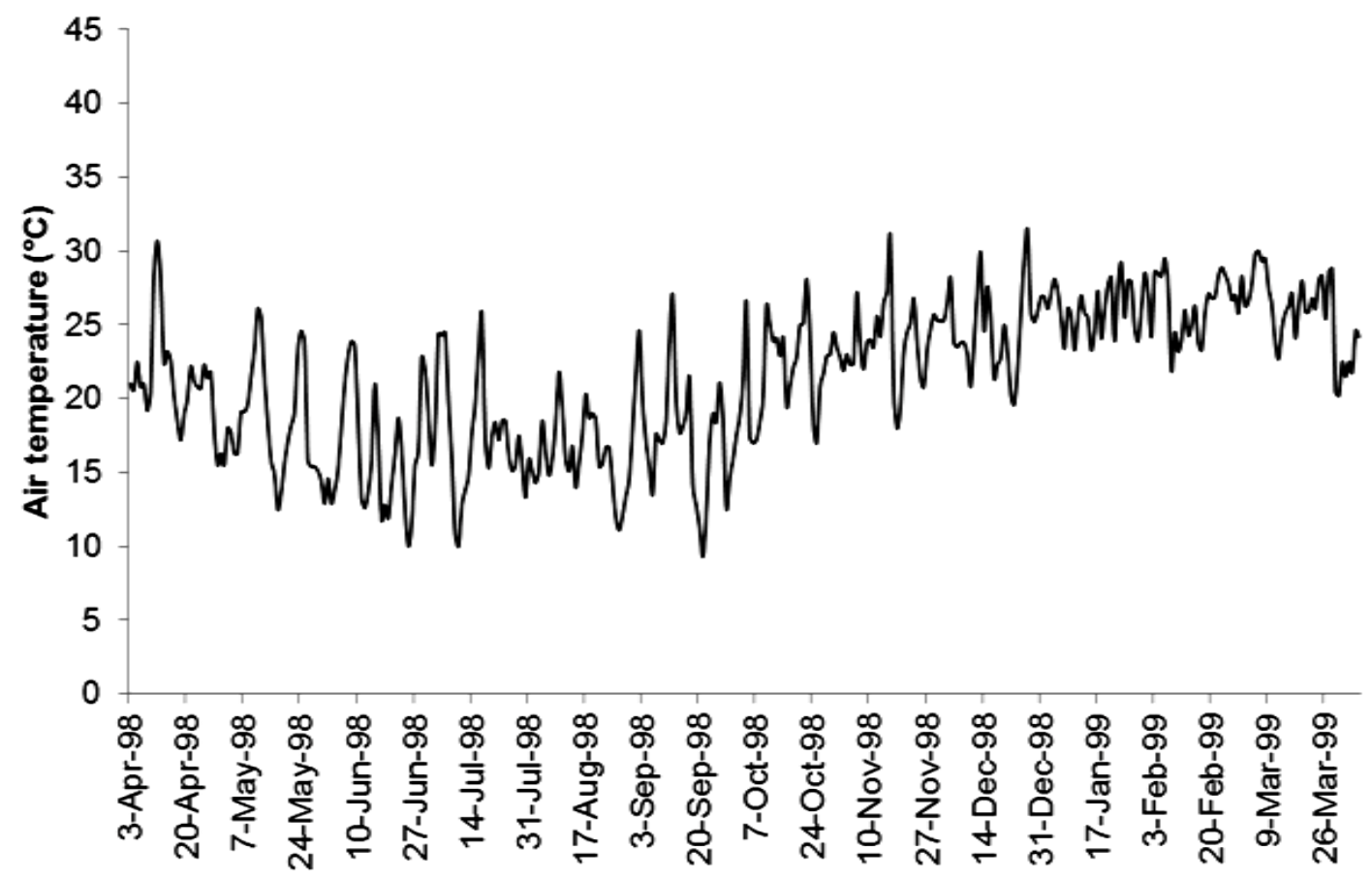

Figure 3. Mean daily variations of air temperature at the study area.

Differences in water temperature between pond A (with water hyacinth cover) and Pond B (without waterhyacinth cover) ranged between $2.1^{\circ} \mathrm{C}$ and $3.6^{\circ} \mathrm{C}$ at 8 a.m. and between $0.1^{\circ} \mathrm{C}$ and $6.4^{\circ} \mathrm{C}$ at 2 p.m. (Figure 4(b) and Figure 5(b)). The highest values were found at the water surface. In both ponds, the temperature reached its minimum at 8 a.m. and 2 p.m. in June (Figure 4(b) and Figure 5(b)), while the maximum values were recorded at 2 p.m. in February and March (pond A and pond B, respectively).

Electrical conductivity (Figure 4(c) and Figure 5(c)) was always lower in pond A than in pond B; the maximum values were recorded in January in both ponds $\left(550 \mu \mathrm{S} \cdot \mathrm{cm}^{-1}\right.$ in pond A and $820 \mu S \cdot \mathrm{cm}^{-1}$ in pond B) at 8 a.m. and 2 p.m. (Figure 4(c) and Figure 5(c)).

Due to the influence of the cover plants, the water remained more acidic in pond A than in pond B (Figure 6(a)), with $\mathrm{pH}$ values ranging between 6.39 and 7.71 at 8 a.m. and between 6.55 and 7.65 at 2 p.m. (Figure 6(b)). This effect was more prominent in the spring and summer.

The MANOVA results suggested a significant difference $(\mathrm{p}<0.0001)$ between ponds with and without water hyacinth, both at 8 a.m. $(\mathrm{F}=185.54)$ and at 2 p.m. $(\mathrm{F}=225.49)$.

\subsection{Comparisons between Lakes and Ponds}

The differences between the lakes (San Nicolás and El Puente) and the conditions of both ponds were analyzed by comparing the measurements carried out at a depth of $0.2 \mathrm{~m}$ at 8 a.m.

There were no significant differences in temperature and $\mathrm{pH}$ values between the lakes and pond A (Table 1). Dissolved oxygen was significantly lower (maximum of $2.15 \mathrm{mg} \cdot \mathrm{L}^{-1}$ ) and electrical conductivity was significantly higher (between 150 and $318 \mu \mathrm{S} \cdot \mathrm{cm}^{-1}$ ) in pond A than in both lakes (Table 1) due to the river overflow in these natural environments.

Dissolved oxygen, electrical conductivity and $\mathrm{pH}$ were significantly higher in pond B (without E. crassipes) than in the lakes (Table 1). The water temperatures were similar during the study period in the floodplain lakes and pond B, and no significant differences were found (Table 1). However, pond B registered the maximum absolute value $\left(28.8^{\circ} \mathrm{C}\right.$, Figure 2(b) and Figure $\left.4(\mathbf{b})\right)$.

\section{Discussion}

Our results suggest that a dense cover (70\% - 90\%) of floating meadows composed of E. crassipes produced 
Table 1. Mean values and standard error of limnological variables of the floodplain lakes and ponds during the study period. Letters different indicate means statistically different (Fisher's test, $\mathrm{p} \leq 0.05$ ).

\begin{tabular}{|c|c|c|c|c|c|c|c|}
\hline & \multicolumn{2}{|c|}{ Lake San Nicolás } & \multicolumn{2}{|c|}{ Lake El Puente } & \multicolumn{3}{|c|}{ ANOVA } \\
\hline & Mean & Standard Error & Mean & Standard Error & $\mathbf{F}$ & d.f. & p value \\
\hline Water temperature $\left({ }^{\circ} \mathrm{C}\right)$ & $17.68^{\mathrm{a}}$ & 2.94 & $18.22^{\mathrm{a}}$ & 3.55 & 0.18 & 24 & 0.6771 \\
\hline Dissolved Oxygen (mg $\cdot \mathrm{l}^{-1}$ ) & $3.17^{\mathrm{b}}$ & 1.37 & $4.34^{\mathrm{a}}$ & 1.13 & 5.64 & 24 & 0.0259 \\
\hline Conductivity $\left(\mu \mathrm{S} \cdot \mathrm{cm}^{-1}\right)$ & $140.62^{\mathrm{a}}$ & 81.78 & $129.77^{\mathrm{a}}$ & 68.40 & 0.13 & 24 & 0.7170 \\
\hline $\mathrm{pH}$ & $7.11^{\mathrm{a}}$ & 0.57 & $7.09^{\mathrm{a}}$ & 0.58 & 0.0004 & 20 & 0.9474 \\
\hline \multirow{2}{*}{8 a.m. } & \multicolumn{2}{|c|}{ Pond A } & \multicolumn{2}{|c|}{ Pond B } & \multicolumn{3}{|c|}{ ANOVA } \\
\hline & Mean & Standard Error & Mean & Standard Error & $\mathbf{F}$ & d.f. & p value \\
\hline Water temperature $\left({ }^{\circ} \mathrm{C}\right)$ & $20.54^{\mathrm{b}}$ & 5.26 & $21.50^{\mathrm{a}}$ & 5.35 & 6.74 & 817 & 0.0096 \\
\hline Dissolved Oxygen $\left(\mathrm{mg} \cdot \mathrm{l}^{-1}\right.$ ) & $0.91^{\mathrm{b}}$ & 0.80 & $4.27^{\mathrm{a}}$ & 3.69 & 323.51 & 817 & 0.0001 \\
\hline Conductivity $\left(\mu \mathrm{S} \cdot \mathrm{cm}^{-1}\right)$ & $271.70^{\mathrm{b}}$ & 69.23 & $330.77^{\mathrm{a}}$ & 116.98 & 77.23 & 817 & 0.0001 \\
\hline $\mathrm{pH}$ & $6.99^{\mathrm{b}}$ & 0.34 & $7.99^{\mathrm{a}}$ & 0.79 & 112.23 & 161 & 0.0001 \\
\hline 2 a.m. & Mean & Standard Error & Mean & Standard Error & $\mathbf{F}$ & d.f. & p value \\
\hline Water temperature $\left({ }^{\circ} \mathrm{C}\right)$ & $21.74^{\mathrm{b}}$ & 5.81 & $23.40^{\mathrm{a}}$ & 6.03 & 16.18 & 817 & 0.0001 \\
\hline Dissolved Oxygen (mg $\cdot \mathrm{l}^{-1}$ ) & $1.19^{\mathrm{b}}$ & 1.07 & $5.76^{\mathrm{a}}$ & 4.68 & 368.97 & 817 & 0.0001 \\
\hline Conductivity $\left(\mu \mathrm{S} \cdot \mathrm{cm}^{-1}\right)$ & $274.84^{\mathrm{b}}$ & 72.93 & $348.25^{\mathrm{a}}$ & 119.87 & 112.02 & 817 & 0.0001 \\
\hline \multirow[t]{3}{*}{$\mathrm{pH}$} & $6.98^{\mathrm{b}}$ & 0.28 & $8.38^{\mathrm{a}}$ & 0.79 & 229.77 & 161 & 0.0001 \\
\hline & \multicolumn{2}{|c|}{ Lake San Nicolás } & \multicolumn{2}{|c|}{ Pond A } & \multicolumn{3}{|c|}{ ANOVA } \\
\hline & Mean & Standard Error & Mean & Standard Error & $\mathbf{F}$ & d.f. & $p$ value \\
\hline Water temperature $\left({ }^{\circ} \mathrm{C}\right)$ & $17.68^{\mathrm{a}}$ & 2.94 & $17.30^{\mathrm{a}}$ & 4.66 & 0.06 & 24 & 0.8074 \\
\hline Dissolved Oxygen $\left(\mathrm{mg} \cdot \mathrm{l}^{-1}\right.$ ) & $3.17^{\mathrm{a}}$ & 1.37 & $1.28^{\mathrm{b}}$ & 0.69 & 19.75 & 24 & 0.0002 \\
\hline Conductivity $\left(\mu \mathrm{S} \cdot \mathrm{cm}^{-1}\right)$ & $140.62^{\mathrm{a}}$ & 81.78 & $243.42^{\mathrm{b}}$ & 49.74 & 15 & 24 & 0.0007 \\
\hline \multirow[t]{3}{*}{$\mathrm{pH}$} & $7.11^{\mathrm{a}}$ & 0.57 & $7.13^{\mathrm{a}}$ & 0.29 & 0.01 & 22 & 0.9368 \\
\hline & \multicolumn{2}{|c|}{ Lake San Nicolás } & \multicolumn{2}{|c|}{ Pond B } & \multicolumn{3}{|c|}{ ANOVA } \\
\hline & Mean & Standard Error & Mean & Standard Error & $\mathbf{F}$ & d.f. & $p$ value \\
\hline Water temperature $\left({ }^{\circ} \mathrm{C}\right)$ & $17.68^{\mathrm{a}}$ & 2.94 & $18.86^{\mathrm{a}}$ & 5.21 & 0.51 & 24 & 0.4822 \\
\hline Dissolved Oxygen (mg $\cdot \mathrm{l}^{-1}$ ) & $3.17^{\mathrm{a}}$ & 1.37 & $8.47^{\mathrm{b}}$ & 3.74 & 23.09 & 24 & 0.0001 \\
\hline Conductivity $\left(\mu \mathrm{S} \cdot \mathrm{cm}^{-1}\right)$ & $140.62^{\mathrm{a}}$ & 81.78 & $270.50^{\mathrm{b}}$ & 70.21 & 18.88 & 24 & 0.002 \\
\hline \multirow[t]{3}{*}{$\mathrm{pH}$} & $7.11^{\mathrm{a}}$ & 0.57 & $8.35^{\mathrm{b}}$ & 0.51 & 31.49 & 22 & 0.001 \\
\hline & \multicolumn{2}{|c|}{ Lake El Puente } & \multicolumn{2}{|c|}{ Pond A } & \multicolumn{3}{|c|}{ ANOVA } \\
\hline & Mean & Standard Error & Mean & Standard Error & $\mathbf{F}$ & d.f. & p value \\
\hline Water temperature $\left({ }^{\circ} \mathrm{C}\right)$ & $18.22^{\mathrm{a}}$ & 1.15 & $17.30^{\mathrm{a}}$ & 1.15 & 0.32 & 24 & 0.5784 \\
\hline Dissolved Oxygen $\left(\mathrm{mg} \cdot \mathrm{l}^{-1}\right.$ ) & $4.34^{\mathrm{a}}$ & 0.25 & $1.39^{\mathrm{b}}$ & 0.26 & 64.61 & 23 & 0.0001 \\
\hline Conductivity $\left(\mu \mathrm{S} \cdot \mathrm{cm}^{-1}\right)$ & $129.77^{\mathrm{a}}$ & 16.59 & $243.42^{b}$ & $16.59^{\mathrm{a}}$ & 23.47 & 24 & 0.0001 \\
\hline \multirow[t]{3}{*}{$\mathrm{pH}$} & $7.09^{\mathrm{a}}$ & 0.13 & $7.13^{\mathrm{a}}$ & 0.12 & 0.03 & 22 & 0.8665 \\
\hline & \multicolumn{2}{|c|}{ Lake El Puente } & \multicolumn{2}{|c|}{ Pond B } & \multicolumn{3}{|c|}{ ANOVA } \\
\hline & Mean & Standard Error & Mean & Standard Error & $\mathbf{F}$ & d.f. & $p$ value \\
\hline Water temperature $\left({ }^{\circ} \mathrm{C}\right)$ & $18.22^{\mathrm{a}}$ & 1.24 & $18.86^{\mathrm{a}}$ & 1.24 & 0.14 & 24 & 0.7149 \\
\hline Dissolved Oxygen (mg $\cdot \mathrm{l}^{-1}$ ) & $4.34^{\mathrm{a}}$ & 0.77 & $8.47^{\mathrm{b}}$ & 0.77 & 14.57 & 24 & 0.0008 \\
\hline Conductivity $\left(\mu S \cdot \mathrm{cm}^{-1}\right)$ & $129.77^{\mathrm{a}}$ & 19.22 & $270.50^{\mathrm{b}}$ & 19.22 & 26.80 & 24 & 0.0001 \\
\hline $\mathrm{pH}$ & $7.09^{\mathrm{a}}$ & 0.16 & $8.35^{\mathrm{b}}$ & 0.15 & 32.10 & 22 & 0.0001 \\
\hline
\end{tabular}



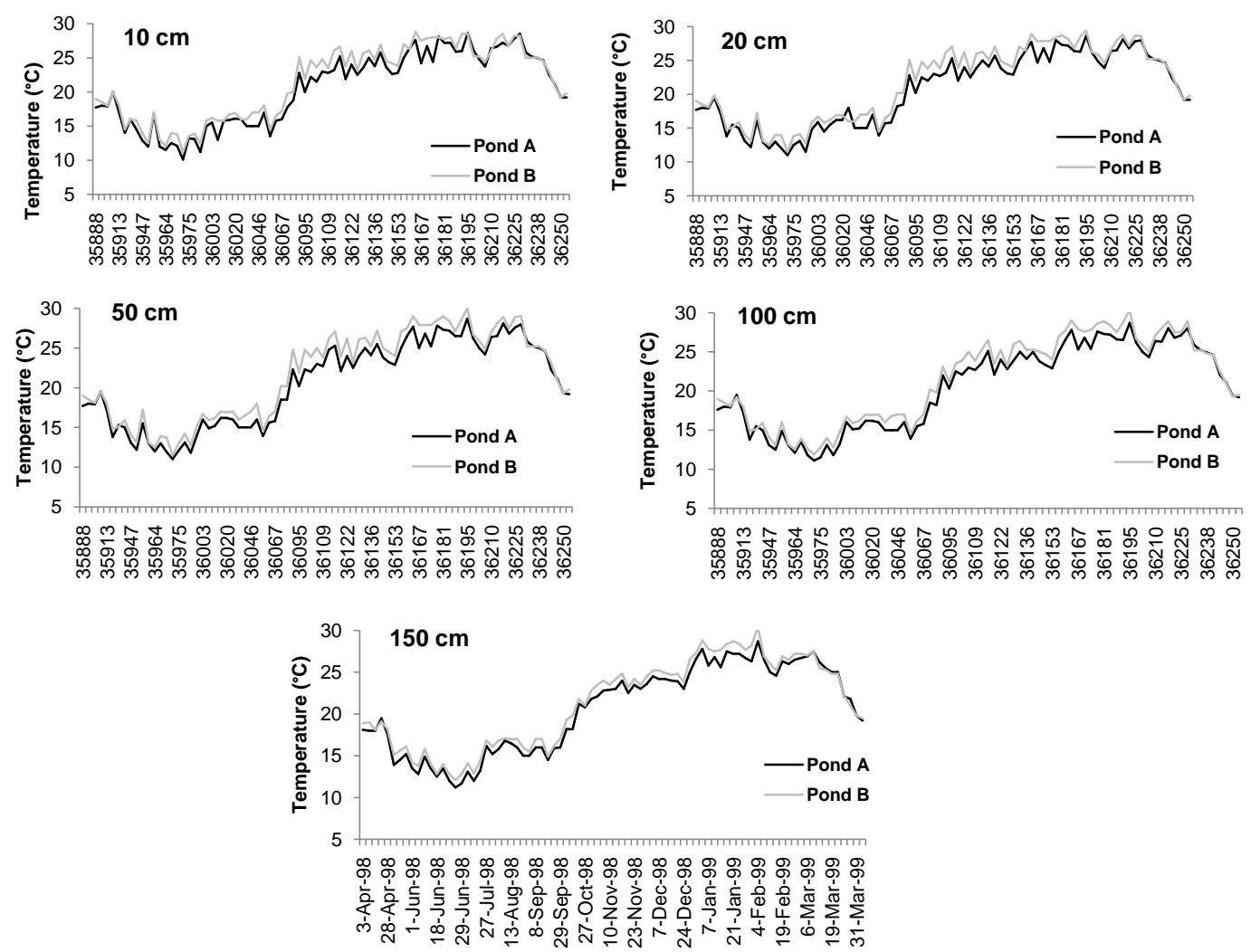

(a)
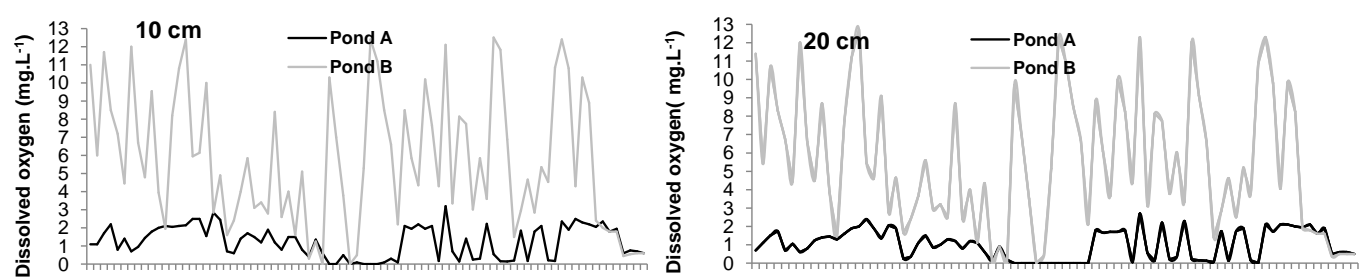

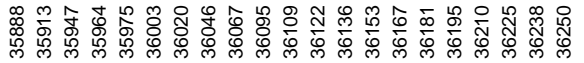
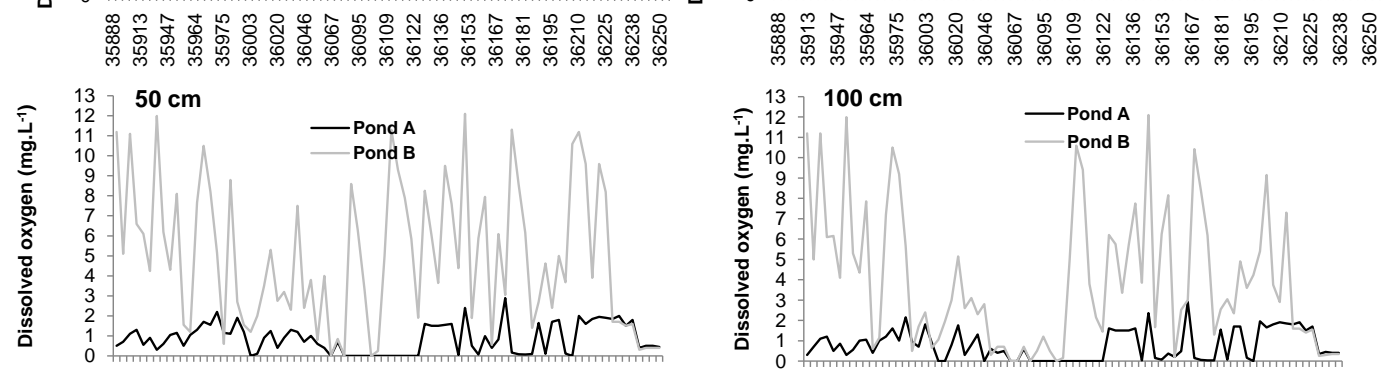

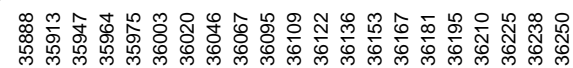

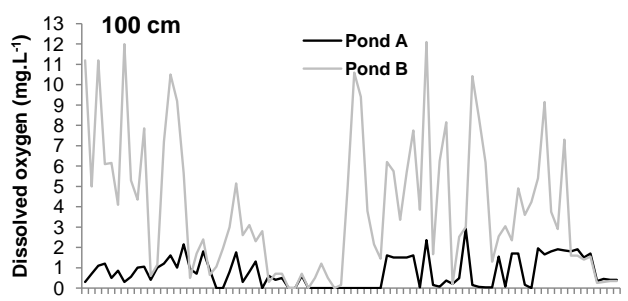

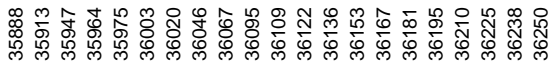

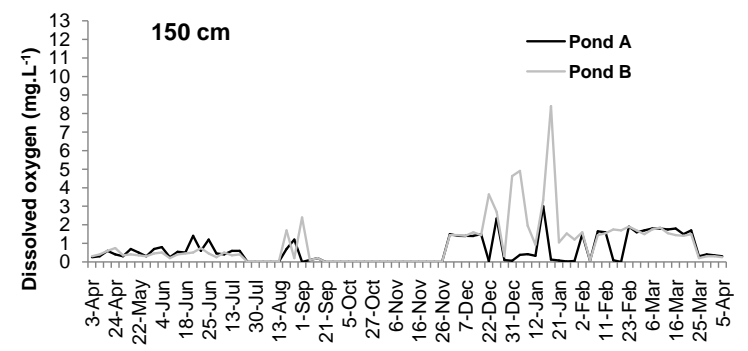

(b) 

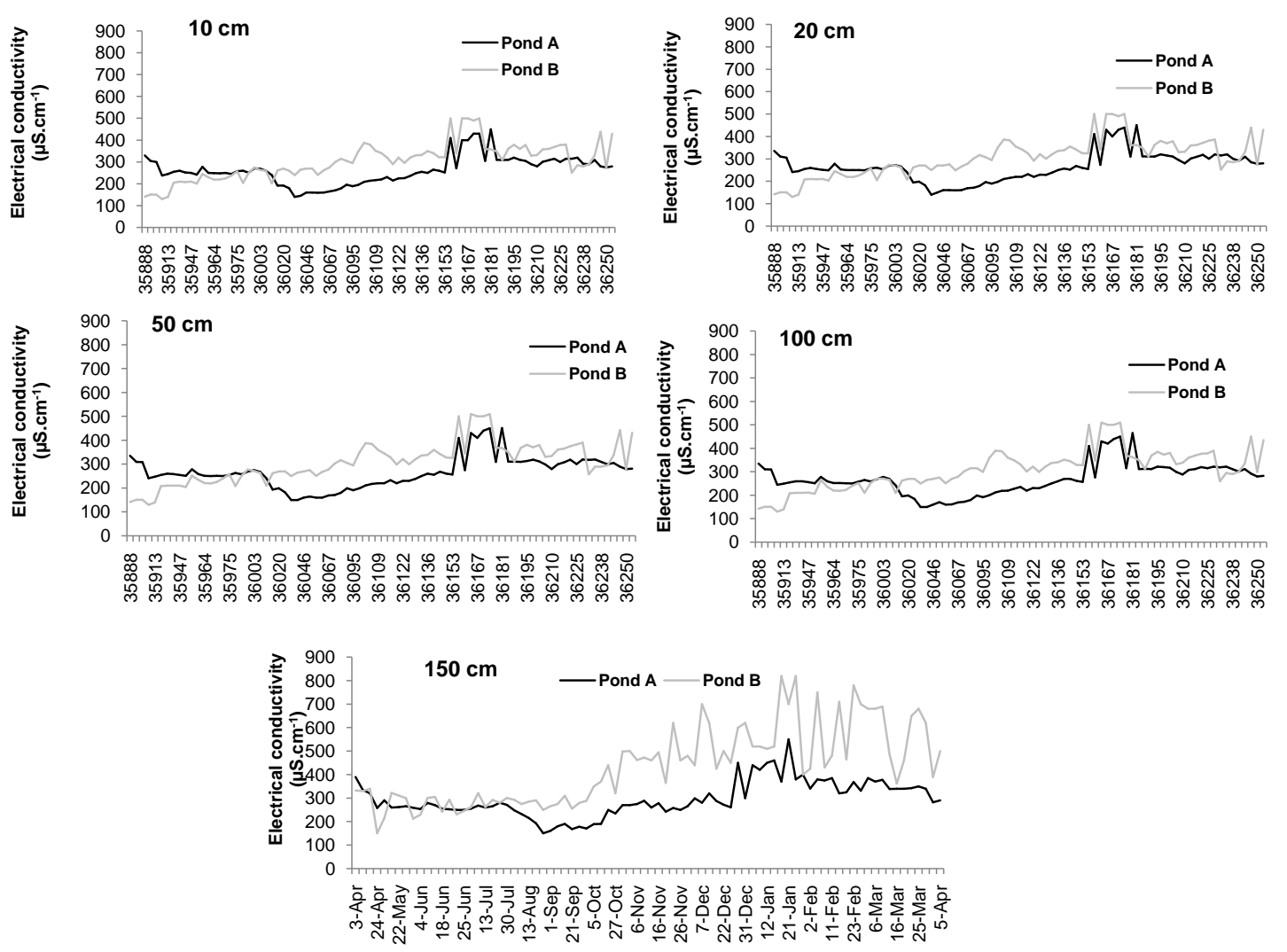

(c)

Figure 4. Variability of dissolved oxygen (a) temperature (b) and electrical conductivity (c) values in pond A (with $E$. crassipes) and pond B (without E. crassipes) at 8 a.m.

changes in dissolved oxygen content, showing a variability pattern that differed from the pattern observed in lakes with submerged vegetation [22]. This plant succeeds in the occupation of both floodplain lakes with different river connectivity [4] [19] and ponds. Generally, less connected lakes have a denser cover of floating meadows than more connected lakes [20]. Under these conditions (less than a 20\% cover), oxygen depletion was not found due to water circulation and diffusion of $\mathrm{O}_{2}$ from the air into the water. When E. crassipes plants occupy the entire water surface, they stop the horizontal circulation of water [3], and during the summer, anoxic conditions were produced. In addition, the decreased oxygen concentration varied directly with the increase in temperature. Thus, we partially accepted the first hypothesis.

The most commonly documented effects of floating meadows are lower dissolved oxygen concentrations [7] [8] [23] [24]. During the decomposition of plant debris in a floodplain lake with a dense cover of E. crassipes, the oxygen concentration remained near zero [15]. Oxygen deficiency caused by aquatic vegetation causes fish mortality in floodplain lakes and in the main course of some tropical South American rivers [25]. Due to light interference, water hyacinth meadows clearly restricted phytoplankton growth [26] [27] and periphyton production [10].

When comparing floodplain lakes that differ in the extent of water hyacinth cover, the current study found significant differences only in dissolved oxygen concentration. In contrast, other studies in subtropical lakes characterized by oversaturation of dissolved oxygen and dominated by submerged plants and phytoplankton showed that water hyacinth had only small effects on temperature and electrical conductivity [28].

In the experimental ponds, a dense cover of $E$. crassipes reduced the water temperature up to $6.4^{\circ} \mathrm{C}$, which was noticeable in the summer and in the afternoon. In the floodplain lake with less E. crassipes cover (El Puente), the highest absolute value of temperature occurred in summer and was $3.2^{\circ} \mathrm{C}$ above the maximum value recorded in the floodplain lake, which had greater water hyacinth coverage. The thermal damping effect produced by plants was negligible only in the winter. Differences in electrical conductivity between ponds with and 

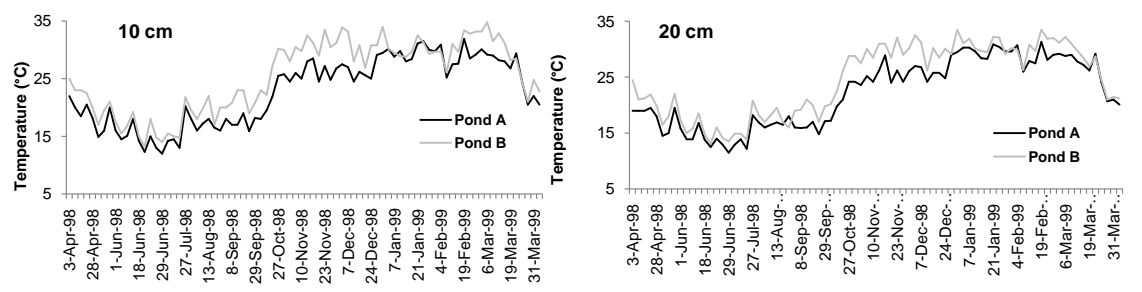

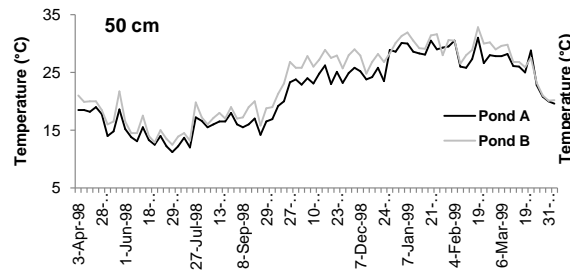
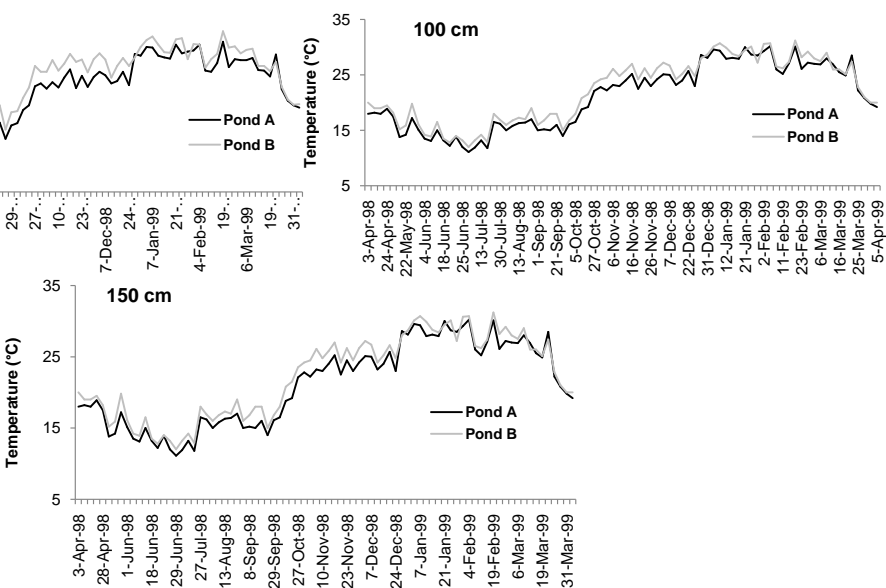

(a)
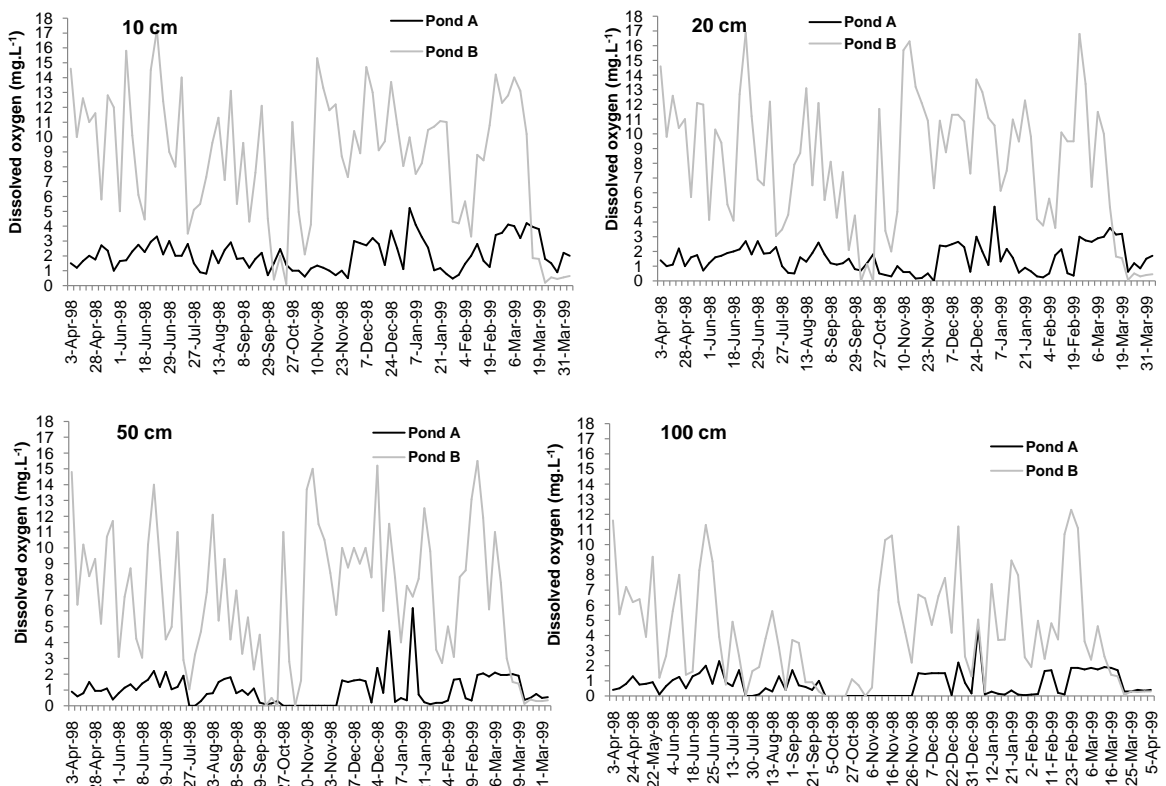

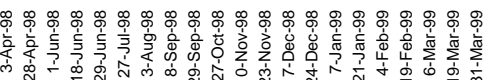

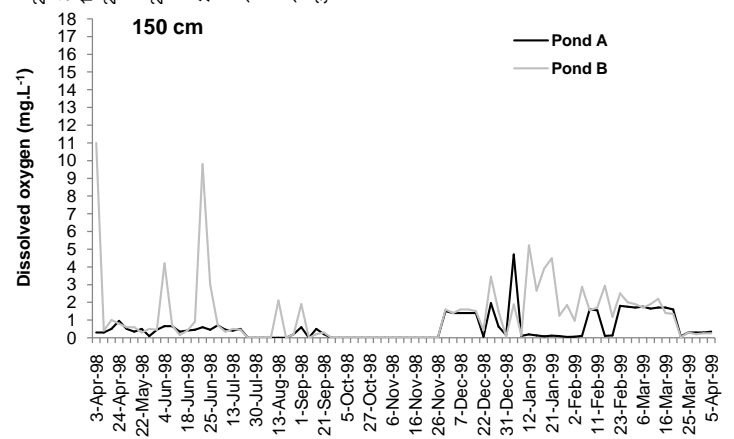

(b) 

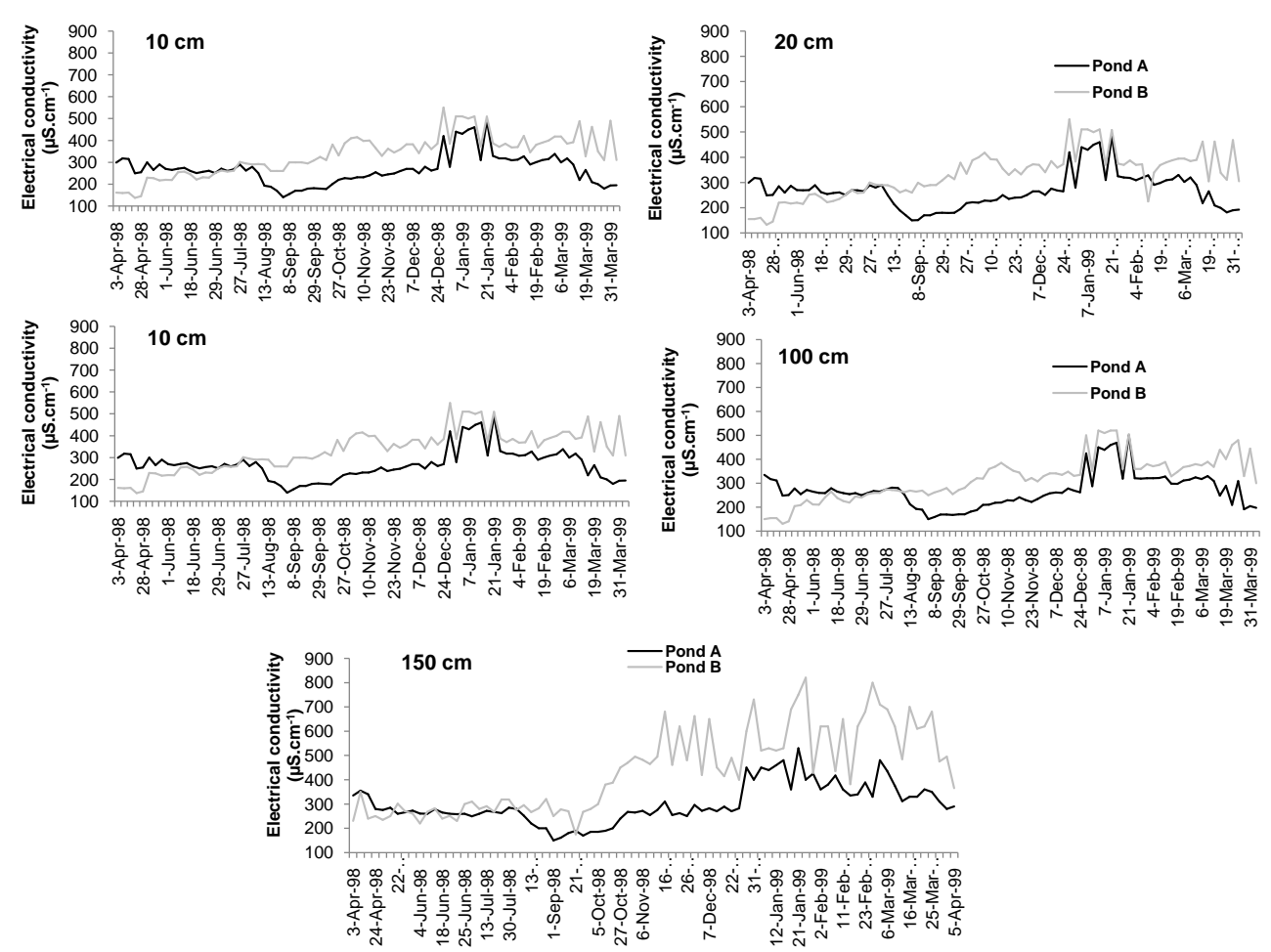

(c)

Figure 5. Variability of dissolved oxygen (a) temperature (b) and electrical conductivity (c) values in pond A (with E. crassipes) and pond B (with E. crassipes) at 2 p.m.

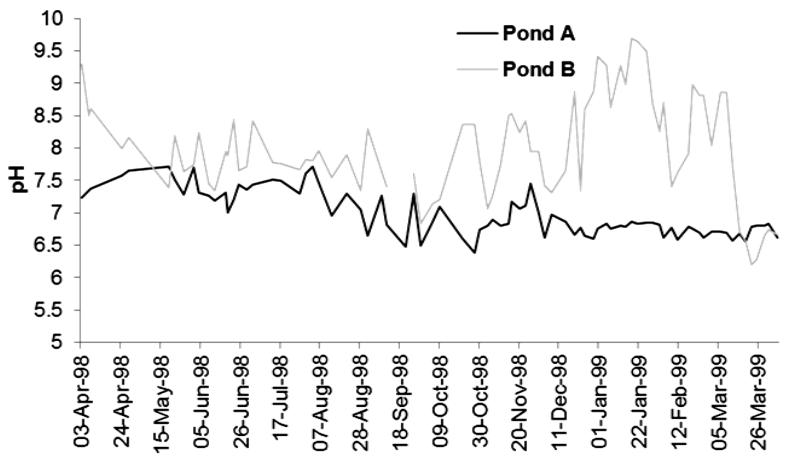

(a)

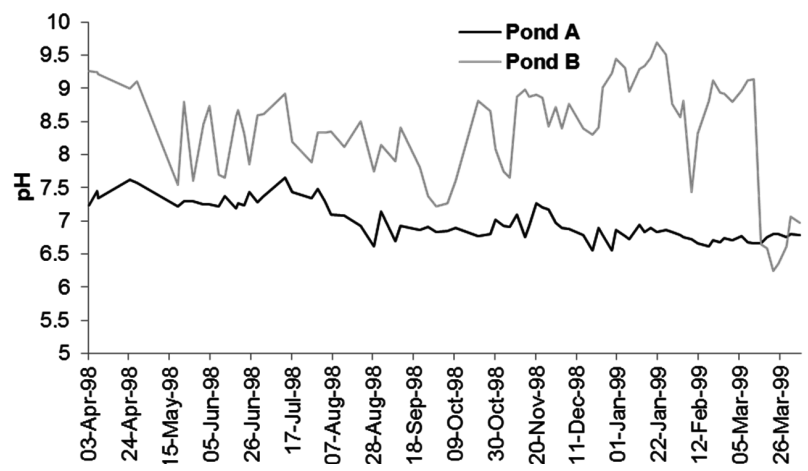

(b)

Figure 6. Variability of pH units at 8 a.m. (a) and 2 p.m. (b). 
without E. crassipes indicated electrolyte capture by the plants. In the summer, $\mathrm{CO}_{2}$ release during plant decomposition creates a reductive environment that decreases the water $\mathrm{pH}$ in the vegetated area.

We did not find changes in dissolved oxygen concentration, electrical conductivity or $\mathrm{pH}$ between the morning and the afternoon. This pattern differs from the one observed in environments with predominantly submerged plants, where high photosynthetic and respiration rates during the day and night yield large changes in dissolved oxygen and $\mathrm{CO}_{2}$ [22] [25]. Consequently, we rejected the third hypothesis.

These results suggest that it is important to include the thermal damping effect produced by floating meadows as a variable in models used to assess the effects of global climate change on wetlands. These floating meadows cover tens of square kilometers of floodplains, such as those of the Paraguay, Paraná and Orinoco Rivers. Our results indicate that water hyacinth produces a strong damping effect on the heating of water bodies, and these results are the basis for the development of spatial models to express results on an experimental scale. Our results show that when water hyacinth covers the entire surface of shallow lakes, it can produce a thermal difference of $2^{\circ} \mathrm{C}-6^{\circ} \mathrm{C}$ during the summer. Moreover, our results may assist in the development of cause-consequence models by demonstrating the relevance of the effect of thermal damping produced by floating meadows. This thermal damping may have indirect effects on other communities because massive fish kills occur due to extreme temperatures and insufficient dissolved oxygen in water [25] [29].

\section{Acknowledgements}

We thank Chet Van Duzer for him valuable suggestions and to our manuscript. María do Carmo Calijuri also contributed important comments for the discussion of the results. We thank the anonymous reviewers who provide useful comments on the manuscript. This study was supported by Projects PIP 11220100100486; PIP 11420100100215; PICT 2077-2008 (CONICET) and 2011Q001 SGCYT (UNNE).

\section{References}

[1] Carignan, R., Neiff, J.J. and Planas, D. (1994) Limitation of Water Hyacinth by Nitrogen in Subtropical Lakes of the Paraná Floodplain (Argentina). Association for the Science of Limnology and Oceanography, 39, 439-443. http://dx.doi.org/10.4319/lo.1994.39.2.0439

[2] Esteves, F.A. and Camargo, A.F.M. (1986) Sobre o papel das macrófitas aquáticas na estocagem e ciclagem de nutrientes. Acta Limnologica Brasiliensia, 1, 273-298.

[3] Carignan, R. and Neiff, J.J. (1992) Nutrient Dynamics in the Floodplain Ponds of the Paraná River (Argentina) Dominated by the Water Hyacinth Eichhornia crassipes. Biogeochemistry, 17, 85-121. http://dx.doi.org/10.1007/BF00002642

[4] Neiff, J.J. (1986) Las grandes unidades de vegetación y ambiente insular del río Paraná en el tramo Candelaria-Itá Ibaté. Revista de la Asociación de Ciencias Naturales del Litoral, 17, 7-30.

[5] Pompêo, M.L., Henry, R., Moschini-Carlos, V. and Padovani, C.R. (1997) A influência da macrófita aquática Echinochloa polystachya (H.B.K.) Hitchcock nas caracteristicas físicas e químicas da água na zona de desembocadura do rio Paranapanema na represa de Jurumirim-SP. Revista Brasileira de Ecologia, 1, 44-53.

[6] Bini, L.M., Thomaz, S.M. and Carvalho, P. (2010) Limnological Effects of Egeria najas Planchon (Hydrocharitaceae) in the Arms of Itaipu Reservoir (Brazil, Paraguay). Limnology, 11, 39-47. http://dx.doi.org/10.1007/s10201-009-0286-4

[7] Esteves, F.A. and Nogueira, F. (1995) The Influence of Floating Meadows and Hydrological Cycle on the Main Abiotic Characteristics of a Tropical Oxbow Lake. Oecologia_Australis, 1, 117-128.

[8] Neiff, J.J., Casco, S.L., Mari, E.K.A., Di Rienzo, J.A. and Poi, A.S.G. (2014) Do Aquatic Plant Assemblages in the Paraná River Change along the River’s Length? Aquatic Botany, 114, 50-57. http://dx.doi.org/10.1016/j.aquabot.2013.12.005

[9] Neiff, J.J. and de Neiff, A.P. (1984) Cambios estacionales en la biomasa de Eichhornia crassipes (Mart.) Solms y su fauna en una laguna del Chaco. Ecosur, 11, 51-60.

[10] Rommens, R., Maes, J., Dekeza, N., Inghelbrecht, P., Nhiwatiwa, T., Holsters, E., Ollevier, F., Marshall, B. and Brendonck, L. (2003) The Impact of Water Hyacinth (Eichhornia crassipes) in a Eutrophic Subtropical Impoundment (Lake Chivero, Zimbabwe). I. Water Quality. Archiv für Hydrobiologie, 158, 373-388. http://dx.doi.org/10.1127/0003-9136/2003/0158-0373

[11] Frutos, S.M. (2001) Abundancia, grupos dominantes y riqueza de especies del zooplancton bajo condiciones de experimentación. Comunicaciones Científicas y Tecnológicas, Universidad Nacional del Nordeste, Corrientes, 1-4. 
[12] Planas, D. and Neiff, J.J (1998) Is Perifiton Important in the E. crassipes Meadows? Verhandlungen des Internationalen Verein Limnologie, 26, 1865-1870.

[13] de Neiff, A.P., Neiff J.J., Orfeo, O. and Carignan, R. (1994) Quantitative Importance of Particulate Matter Retention by the Roots of Eichhornia crassipes in the Paraná Floodplain. Aquatic Botany, 47, 213-223. http://dx.doi.org/10.1016/0304-3770(94)90054-X

[14] de Neiff, A.P. and Neiff, J.J. (1988) Decomposition of Eichhornia crassipes (Mart.) Solms in a Pond of Paraná River Valley and Colonization by Invertebrates. Tropical Ecology, 29, 79-85.

[15] de Neiff, A.P., Neiff, J.J. and Casco, S.L. (2006) Leaf Litter Decomposition in Three Wetlands of the Paraná River Floodplain. Wetlands, 26, 558-566. http://dx.doi.org/10.1672/0277-5212(2006)26[558:LLDITW]2.0.CO;2

[16] Bottino, F., Calijuri, M.C. and Murphy, K.J. (2013) Temporal and Spatial Variation of Limnological Variables and Biomass of Different Macrophyte Species in a Neotropical Reservoir (São Paulo, Brazil). Acta Limnologica Brasiliensia, 25, 387-397. http://dx.doi.org/10.1590/S2179-975X2013000400004

[17] Bini, L.M., Thomaz, S.M., Murphy, K.J. and Camargo, A.F.M. (1999) Aquatic Macrophyte Distribution in Relation to Water and Sediment Conditions in Itaipu Reservoir, Brazil. Hydrobiologia, 415, 147-154. http://dx.doi.org/10.1023/A:1003856629837

[18] Bini, L.M., Oliveira, L.G., Souza, D.C., Carvalho, P. and Pinto, M.P. (2005) Patterns of the Aquatic Macrophyte Cover in Cachoeira Dourada Reservoir (GO-MG). Brazilian Journal of Biology, 65, 19-24. http://dx.doi.org/10.1590/S1519-69842005000100004

[19] Neiff, J.J., de Neiff, A.S.G.P. and Casco, S.L. (2001) The Effect of Prolonged Floods on Eichhornia crassipes Growth in Paraná River Floodplain Lakes. Acta Limnologica Brasiliensia, 13, 51-60.

[20] Neiff, J.J., Casco, S.L. and de Neiff, A.S.G.P. (2008) Response of Eichhornia crassipes (Pontederiaceae) to Water Level Fluctuations in Two Lakes with Different Connectivity in the Paraná River Floodplain. Revista de Biología Tropical, 56, 613-623.

[21] Di Rienzo, J.A., Casanoves, F., Balzarini, M.G., González, L., Tablada, M. and Robledo, C.W. (2013) InfoStat Versión 2013. Grupo InfoStat, FCA, Universidad Nacional de Córdoba, Córdoba. http://www.infostat.com.ar

[22] Kalff, J. (2002) Limnology. Inland Water Ecosystems. Prentice Hall, Upper Saddle River.

[23] Esteves, F.A. (2011) Fundamentos de Limnologia. Editora Interciencia/FINEP.

[24] Perna, C. and Burrows, D. (2005) Improved Dissolved Oxygen Status Following Removal of Exotic Weed Mats in Important Fish Habitat Lagoons of the Tropical Burdekin River Floodplain, Australia. Marine Pollution Bulletin, 51, 138148. http://dx.doi.org/10.1016/j.marpolbul.2004.10.050

[25] Hamilton, S.K., Sippel, S.J., Calheiros, D.F. and Melack, J.M. (1997) An Anoxic Event and Other Biogeochemical Effects of the Pantanal Wetland on the Paraguay River. Limnology and Oceanography, 42, 257-272. http://dx.doi.org/10.4319/lo.1997.42.2.0257

[26] de Domitrovic, Y.Z. (1993) Fitoplancton de una laguna vegetada por Eichhornia crassipes. Ambiente Subtropical, 3 , 39-67.

[27] Flöder, S. and Sommer, U. (1999) Diversity in Planktonic Communities: An Experimental Test of the Intermediate Disturbance Hypothesis. Limnology and Oceanography, 44, 1114-1119. http://dx.doi.org/10.4319/lo.1999.44.4.1114

[28] Meerhoff, M., Mazzeo, N., Moss, B. and Rodríguez-Gallego, L. (2003) The Structuring Role of Free-Floating versus Submerged Plants in a Subtropical Shallow Lake. Aquatic Ecology, 37, 377-391. http://dx.doi.org/10.1023/B:AECO.0000007041.57843.0b

[29] Neiff, J.J. and Neiff, M. (2013) Evaluación de los impactos del cambio climático sobre el ecosistema natural y la biodiversidad. Esteros del Iberá (Argentina). CEPAL-Serie Medio Ambiente y Desarrollo. Publicación de las Naciones Unidas, Chile, 152, 1-59. 